\title{
GERMINATIVE PERFORMANCE OF MULUNGÚ SEEDS (Ormosia grossa RUDD) AFTER DORMANCY OVERCOMING
}

\author{
Romário de Mesquita Pinheiro ${ }^{2 *} \odot$, Vanessa Nogueira Soares $^{3} \odot$, Gizele Ingrid Gadotti ${ }^{4}$,

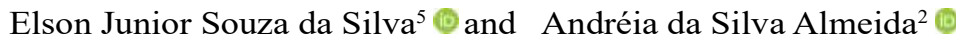

\footnotetext{
${ }^{1}$ Received on 14.11.2020 accepted for publication on 28.06.2021.

${ }^{2}$ Universidade Federal de Pelotas, Programa de Pós-Graduação em Ciência e Tecnologia de Sementes, Pelotas, RS - Brasil. E-mail: $<$ romario.ufacpz@hotmail.com>and <andreiasalmeida@yahoo.com.br>.

${ }^{3}$ Fundação Espírito-Santense de Tecnologia, Goiabeiras, Vitória, ES - Brasil. E-mail: <vnsoares@gmail.com>.

${ }^{4}$ Universidade Federal de Pelotas, Centro de Engenharias, Pelotas, RS - Brasil. E-mail: < gizeleingrid@gmail.com>.

${ }^{5}$ Universidade de São Paulo, Programa de Pós-Graduação em Recursos Florestais, Butantã, SP - Brasil. E-mail: <elsonjrsouza@hotmail. com>.

*Corresponding author.
}

\begin{abstract}
Ormosia grossa Rudd is an Amazonian species that presents bicolor seeds, allowing its exploration for handicraft and decoration making. This paper aimed to analyze the influence of different methods to overcome dormancy on the germinative performance of Ormosia grossa seeds. To conduct the experiment, the following treatments were established: $\mathrm{T} 1=$ scarification with 80 -grit sandpaper and water immersion at room temperature for 24 hours; $\mathrm{T} 2=$ puncturing and water immersion at room temperature for 24 hours; $\mathrm{T} 3=$ scarification with 80 -grit sandpaper; $\mathrm{T} 4=$ puncturing; $\mathrm{T} 5=$ immersion in water heated to $80^{\circ} \mathrm{C}$ for five minutes, and $\mathrm{T} 6=$ Control - seeds without any treatment. The seeds germinate slowly and irregularly. Depending on the treatment, germination started between 10 and 32 days and, if there is no adequate pre-germinative treatment to overcome dormancy, it can exceed such time. The phytomass performance and seedling lengths were superior in the $\mathrm{T} 1$ and $\mathrm{T} 2$ treatments. The scarification by abrasiveness and puncturing treatments are efficient to overcome dormancy, thus increasing the speed (3.76 and 3.12) and germination percentage $(98 \%$ and $96 \%$ ) after ten days. The control was 0.01 (IVG), and germination of $37 \%$. Therefore, it is recommended the method of scarification with sandpaper followed by seed imbibition in water at room temperature for 24 hours, as it provides the best seedling performance and germination.
\end{abstract}

Keywords: Amazonian species, Fabaceae, Integument impermeability.

\section{DESEMPENHO GERMINATIVO DE SEMENTES DE MULUNGÚ (Ormosia grossa RUDD) APÓS SUPERAÇÃO DE DORMÊNCIA}

\begin{abstract}
RESUMO - Ormosia grossa Rudd é uma espécie amazônica que apresenta sementes bicolores, o que permite sua exploração para confecção de artesanatos e decorações. Esse trabalho teve como objetivo analisar a influência de diferentes métodos de superação de dormência no desempenho germinativo de sementes de Ormosia grossa. Para a condução do experimento, foram estabelecidos tratamentos: $T 1=$ escarificação com lixa número 80 e imersão em água à temperatura ambiente por 24 horas; T2 = punção e imersão em água à temperatura ambiente por 24 horas; T3= escarificação com lixa número 80; T4= punção; T5= imersão em água aquecida a $80^{\circ} \mathrm{C}$ por cinco minutos e T6=Controle - sementes sem nenhum tratamento. As sementes germinam de forma lenta e irregular. Dependendo do tratamento, a germinação iniciou-se entre 10 a 32 dias $e$, se não houver tratamento pré-germinativo adequado para superar a dormência, pode ultrapassar esse tempo. O desempenho de fitomassa e comprimentos de plântulas foram superiores nos tratamentos T1 e T2. Os tratamentos com escarificação por abrasividade e perfuração são eficientes na superação de dormência, aumentando a velocidade $(3,76$ e 3,12) e o percentual de germinação (98\% e 96\%), após 10 dias. O controle foi de 0,01 (IVG) e germinação de 37\%. Portanto, é recomendado o método de escarificação com lixa seguida de embebição das sementes em água à temperatura ambiente por 24 horas, pois proporciona o melhor desempenho das plântulas e germinação.
\end{abstract}

Palavras-Chave: Espécie Amazônica, Fabaceae, Impermeabilidade do tegumento.

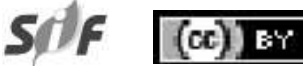

Revista Árvore 2021;45:e4532 http://dx.doi.org/10.1590/1806-908820210000032 


\section{INTRODUCTION}

In some species, seeds do not germinate even when environmental conditions are favorable (Gama et al., 2011). This happens due to the impermeability of integument associated with several botanical species, more frequently those of the Fabaceae family (Carvalho and Nakagawa, 2012). This characteristic is associated with the hardness of the seeds and the tegument histology (Venier et al., 2012). The seed coat's histological characteristics are related to the epidermal cells compacted in palisades and various chemical substances (lignin, calluses, lipids, phenolic deposits, cutin, wax, and suberin) in any layer of the coat (Jayasuriya et al., 2007). Besides, hormones such as abscisic acid (ABA) and gibberellic acid (GA) can influence the type of dormancy and seed germination (Kang et al., 2015) because they act as integrators between environmental signals and molecular signals for the regulation of gene expression. Therefore, the balance between ABA and GA content and sensitivity is critical in regulating seed dormancy and germination status (Tognacca and Botto, 2021).

Among the methods to overcome physical dormancy, the mechanical scarification - the partial rupture of the integument of the seed, affects its metabolic process and consequently, the dormancy, since such method provides better conditions for water absorption, gas permeability, light, and temperature sensibility (Basqueira et al., 2011).

The Ormosia Jacks genus is part of the Fabaceae family and comprises 130 species, 80 of which occur in Central and South America, whilst the remaining can be found in Asia and Australia. In this context, Ormosia grossa seeds are commonly used to make handcrafted products due to their stand-out coloring, as they are red with black spots. This species presents pod-like fruits and disperses its seeds in the Amazonian summer between June to September. However, there is still no detailed information on its germination process and neither on seedlings production.

Therefore, there is no available information about seed handling and analysis for most native forest species, to provide data to characterize physical and physiological attributes. Basic information on the germination, cultivation, and potentiality of native species is needed to improve seedling production in forest nurseries, ensure good seed emergence in forest restoration projects through some techniques such as direct sowing (Araújo et al., 2012).

For seeds of Ormosia arborea and Ormosia nitida Vog, Lorenzi (2010), and Lopes et al. (2006), recommend mechanical scarification before sowing to increase germination. Ormosia grossa seeds - although there is no specific information, present several obstacles to germination, due to being covered by a hard integument that restrains water flow. Therefore, this paper aimed to analyze the influence of different methods to overcome dormancy on the germinative performance of Ormosia grossa seeds.

\section{MATERIALS AND METHODS}

The experiment was conducted at the Didactic Laboratory of Seed Analysis of the post-graduation program at the Federal University of Pelotas, located in Capão do Leão, RS. The authors used freshly harvested seeds of Ormosia grossa from the Humaitá forest reserve, in the research area of the Acre Federal University in Porto Acre, AC. The seeds were dispersed from June to September, being collected in the soil.

To accomplish the dormancy overcoming experiment, the seeds were submitted to the following treatments: $T_{1}=80$-grit sandpaper scarification and 24-hours immersion in water at room temperature; $\mathrm{T}_{2}$ $=$ Puncturing and 24-hours immersion in water at room temperature; $\mathrm{T}_{3}=80$-grit sandpaper scarification; $\mathrm{T}_{4}=$ puncturing; $\mathrm{T}_{5}=$ immersion in water heated at $80^{\circ} \mathrm{C}$ for five minutes and $\mathrm{T}_{6}=$ Control: - seeds without any treatment to overcome dormancy.

The seed mechanical scarification was made 180 degrees from the seed hilum (in the opposite direction from the hilum). The puncturing was performed by a perforation in the lateral medial portion of the seed until it surpassed the $0.10 \mathrm{~mm}$ thickness of the integument.

One hundred seeds were used per treatment, divided into four repetitions of 25 seeds, sown on three sheets of Germitest ${ }^{\circledR}$ paper moistened with distilled water, in an amount corresponding to 2.5 times the weight of dry paper (MAPA, 2009). The seeds were kept in a germination chamber at $30^{\circ} \mathrm{C}$ temperature under continuous light exposure (artificial fluorescent lamps). The germinated seed ones were counted daily, considering as germinated those who presented

Revista Árvore 2021;45:e4532 
epicotyl emission and development of its first pair of leaves (germination from the technological point of view). The duration of the experiment was 90 days.

Germination percentage $(\mathrm{G} \%)$, mean germination time (MGT), mean germination speed (MGS), the relative frequency of germination (RF), and germination speed index (GSI) were evaluated. The G\%, MGT, MGS were calculated according to equations cited by Labouriau and Valadares (1976):

- Germination percentage $(\mathrm{G} \%)$ :

$\mathrm{G}=\left(\frac{\mathrm{N}}{\mathrm{A}}\right) \cdot 100$

In which: $\mathrm{G}=$ germination percentage; $\mathrm{N}=$ number of germinated seeds; $\mathrm{A}=$ total number of seeds set to germinate.

- Mean germination time (MGT):

$\mathrm{t}=\frac{\left(\sum_{i=1}^{k} n i \cdot t i\right)}{\sum_{i=1}^{k} n i}$

In which: $\mathrm{t}=$ mean incubation time; $\mathrm{ni}=$ number of seeds germinated per day; $\mathrm{ti}=$ incubation time (days).

- Mean germination speed (MGS):

$\mathrm{S}=\frac{1}{t}$

In which: $\mathrm{S}=$ mean germination speed (days); $\mathrm{t}=$ mean germination time.

The relative frequency of germination and germination speed index were estimated according to Lopes and Franke, (2011):

$\mathrm{RF}=\frac{\mathrm{ni}}{\sum_{\mathrm{i}=1}^{\mathrm{k}} \mathrm{ni}}$

In which: $\mathrm{RF}=$ relative germination frequency; $\mathrm{ni}=$ number of germinated seeds per day, $\Sigma \mathrm{ni}=$ total number of germinated seeds.
$=\mathrm{GSI}=\frac{\mathrm{G} 1}{\mathrm{~N} 1}+\frac{\mathrm{G} 2}{\mathrm{~N} 2}+\frac{\mathrm{G} 3}{\mathrm{~N} 3} \ldots \frac{\mathrm{GN}}{\mathrm{NN}}$

Eq.5

In which: GSI= germination speed index; G1, G2, Gn mean the number of seeds germinated at the first, second, and last count, and N1, N2, Nn represent the number of the days after sowing, equivalent to the first, second, and last count.

At the end of the evaluation, the seedlings were measured, assessing means root length (RL), mean shoot length (SL), and total mean length (TL) using a millimeter ruler. The results were described in centimeters. The fresh mass of the aerial part, root, and the total mass was analyzed with the aid of an analytical balance (precision $\sim 0.0001 \mathrm{~g}$ ), and then the dry mass of the aerial part (SDM), root (RDM), and total mass (TDM) was also determined. For dry mass determination, the plant material was placed in a drying oven with forced air at $75^{\circ} \mathrm{C}$ until a constant mass was obtained. Said mass was determined in grams. The experimental design was completely randomized in a $6 \times 4$ factorial scheme (six treatments and four repetitions). The obtained data were submitted to variance analysis when the $\mathrm{F}$ test was significant. The mean comparison was performed using the Tukey test at a $5 \%$ probability. The software used for the analysis was winStat (Machado et al., 2001).

\section{RESULTS}

Ormosia grossa seeds germinate slowly and irregularly, according to the treatment used. When submitted to dormancy overcoming, a period of 10 days after sowing was verified for the beginning of germination. When no method was performed,

Table 1 - Mean values of the Germination Speed Index (GSI), Mean Germination Time (MGT), Mean Germination Speed (MGS) and germination percentage $(\mathrm{G} \%)$ of Ormosia grossa seeds.

Tabela 1 -Valores médios de indice de velocidade de germinação (IVG), tempo médio de germinação (TMG), velocidade média de germinação (VMG) e porcentagem de germinação $(G \%)$ de sementes de Ormosia grossa.

\begin{tabular}{|c|c|c|c|c|}
\hline Treatments & GSI & MGT (days) & MGS (days ${ }^{-1}$ ) & $\overline{G \%}$ \\
\hline $\mathrm{T}_{1}$ - Sandpaper scarification $+\mathrm{H}_{2} \mathrm{O} / 24 \mathrm{~h}$ & $3.76 \mathrm{a}$ & $10 \mathrm{a}$ & $0.1 \mathrm{a}$ & $\overline{98 \mathrm{a}}$ \\
\hline $\mathrm{T}_{2}-$ Puncturing $+\mathrm{H}_{2} \mathrm{O} / 24 \mathrm{~h}$ & $3.12 b$ & $10 \mathrm{a}$ & $0.092 b$ & $96 \mathrm{a}$ \\
\hline $\mathrm{T}_{3}$ - Sandpaper scarification & $3.07 \mathrm{~b}$ & $10 \mathrm{a}$ & $0.097 \mathrm{ab}$ & $86 a$ \\
\hline $\mathrm{T}_{4}-$ Puncturing & $0.83 c$ & $13 a$ & $0.074 \mathrm{c}$ & $67 b$ \\
\hline $\mathrm{T}_{5}$ - Immersion in $\mathrm{H}_{2} \mathrm{O} 80^{\circ} \mathrm{C} / 5$, & $0.11 \mathrm{~d}$ & $21 b$ & $0.046 \mathrm{~d}$ & $40 c$ \\
\hline $\mathrm{T}_{6}$ - Control & $0.01 \mathrm{~d}$ & $32 \mathrm{c}$ & $0.030 \mathrm{e}$ & $37 \mathrm{c}$ \\
\hline Mean value & 1.81 & 16.12 & 0.073 & 70 \\
\hline$\overline{C V(\%)}$ & 15.08 & 10.56 & 3.08 & 8.17 \\
\hline
\end{tabular}


germination began in 21 days. Such a late germination process occurs due to dormancy caused by the integument impermeability. It is common in most species belonging to the Fabaceae family.

Germination speed index (GSI), mean germination time (MGT), mean germination speed (MGS), and germination percentage ( $\mathrm{G} \%$ ) characterize the germinative behavior of the species and allow further understanding regarding reproductive aspects (Table 1).

The mean values presented for seeds scarified with sandpaper and soaked in water for 24 hours were higher than in other treatments, indicating a better result in GSI, yet there was no difference in MGS regarding the first three treatments (sandpaper soaked in water for 24 hours, puncturing plus water soaking and sandpaper scarification). There was no difference in MGT among the four initial treatments (Sandpaper scarification $+\mathrm{H}_{2} \mathrm{O} / 24 \mathrm{~h}$, Puncturing $+\mathrm{H}_{2} \mathrm{O} / 24 \mathrm{~h}$, Sandpaper scarification and Puncturing). Germination percentage did not differ in scarification with 80 -grit sandpaper and water immersion at room temperature for 24 hours, puncturing, and 24-hours immersion in water at room temperature and 80 -grit sandpaper scarification, demonstrating high germination ( $\geq 86 \%$ ) when such methods for dormancy overcoming are applied (Table 1).

Germination began on the tenth day after the experiment had been installed for all treatments except for control, in which germination began after the twentieth day (Table 1). The distribution of germination frequency evidenced polymodality for puncturing, immersion in water heated at 80 ${ }^{\circ} \mathrm{C}$ for five minutes, and control treatments when the polygonal line touches the horizontal axis more than once, indicating several germination peaks (Figure 1e and 1f). As for sandpaper scarification and water immersion at room temperature for 24 hours, puncturing and water immersion at room temperature for 24 hours followed by sanding: unimodality was shown, characterizing germination homogeneity (Figure 1a and 1b).

Based on the daily germination frequency distribution, the following observations were made: in the scarification with sandpaper and water immersion, puncturing and water immersion and sandpaper treatments, the highest germination rate occurred between 10 and 13 days after sowing, completing the entire germinative process in a maximum of eight days after the first evaluation, quickly and regularly. As for puncturing, the highest peak occurred between days 10 and 13, with a lower number of germinated seeds per day, characterizing several peaks during evaluation and perduring for another 11 days.

The soaking in water heated at $80^{\circ} \mathrm{C}$ for 5 minutes treatment showed no expressivity in the number of germinated seeds per observed day, starting on the tenth day and slowly extending for further 33 days with several germination peaks. The control treatment seeds began their germinative processes on the twentieth day after sowing, which was extended for further 40 days, showing that the natural germinative process happens slowly and irregularly.

During the evaluation of the length of the seedlings, some difference was observed between treatments scarification with 80-grit sandpaper and water immersion at room temperature for 24 hours and control for the analyzed variables (Figure 2). The seedling originated from seeds that received the scarification followed by water immersion for 24 hours treatment showed greater total length when compared to the ones derived from the puncturing, hot water soaking and control treatments. There was no statistical difference between the treatments evaluated for root length $(\mathrm{P}>0.05)$.

As for the total fresh mass and the shoot fresh mass, the sandpaper scarification and water soaking, puncturing and water soaking treatments stand out yet again, showing superior results to the control (Figure 3 ). The accumulation in the biomass following the treatments of higher values of phytomass may be associated with the high vigor of seeds that express their maximum performance after germination.

As for the dry mass of the seedlings, the best results were also observed for the sandpaper scarification and water soaking for 24 hours treatment for all the variables, being superior to the other methods for TFM and SDM, and also the only treatment which differs to the Control in all evaluated variables (Figure 3 ). The higher values were observed in the cited treatment because the seeds present a higher germination speed, resulting in the most prolonged dry mass accumulation period until evaluation day.

Revista Árvore 2021;45:e4532 
Source: the authors.

Fonte: elaboração própria
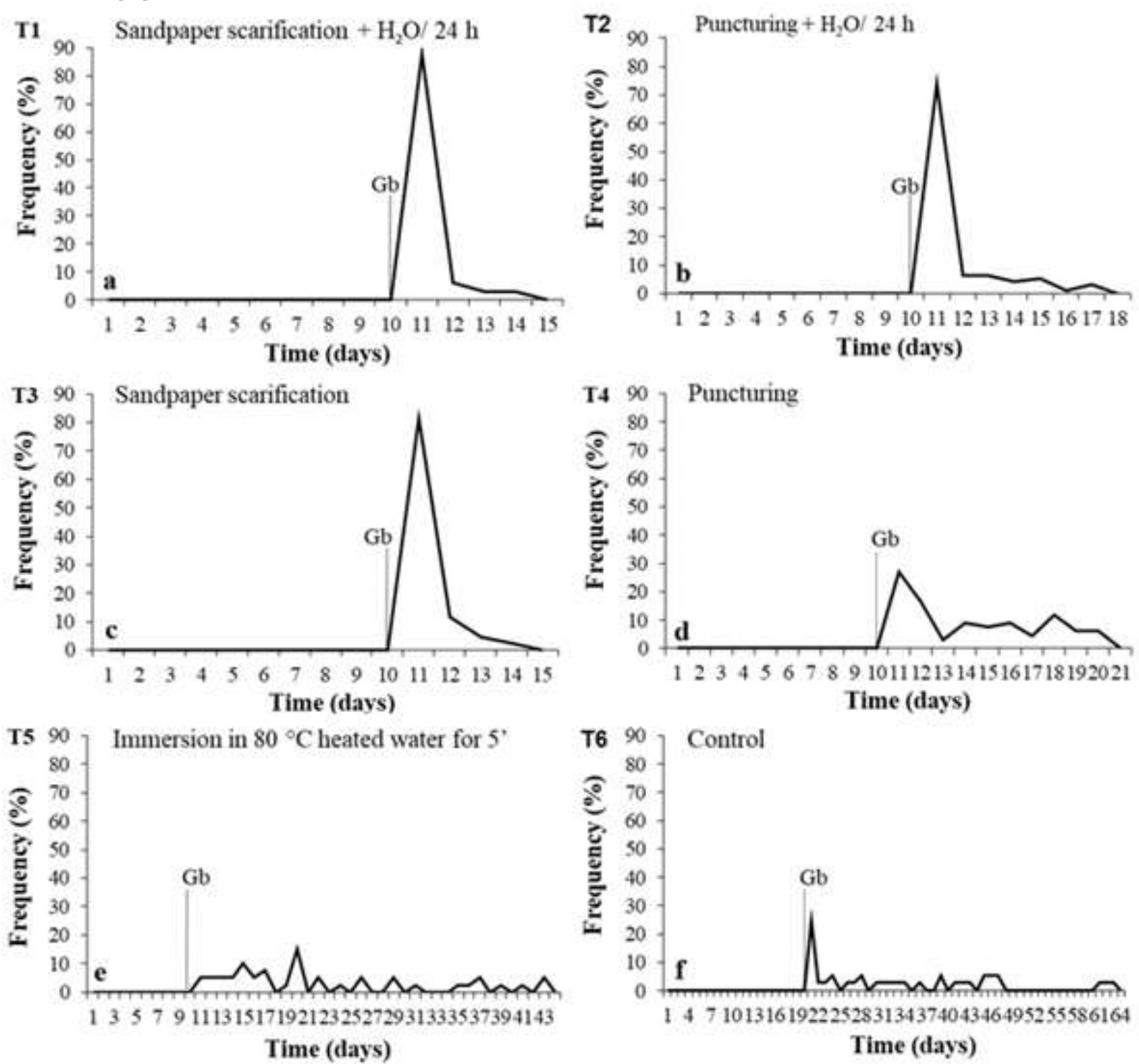

Figure 1 - Germination frequency distribution of Ormosia grossa seeds submitted to different dormancy overcoming methods. h= hours; $\mathrm{Gb}$ - Germination beginning; 5'- five minutes; $\mathrm{H}_{2} \mathrm{O}$ - water.

Figura 1 -Distribuição de frequência da germinação de sementes de Ormosia grossa submetidos a diferentes métodos de superação de dormência. $h=$ horas; Ig (Gb)-Inicio da germinação; 5 '- cinco minutos; $\mathrm{H}_{2} \mathrm{O}$ - água.

The lowest mean values were found in the seed immersion in water heated at $80{ }^{\circ} \mathrm{C}$ for five minutes and control treatments, which were not adequate for seedling establishment due to an uneven and slow germination process. On the other hand, abrasive scarification and perforations favor the seedling establishment and a higher germination speed and should be recommended to achieve uniform germination. When the seed coat is broken down and soaked in water, it speeds up metabolic activation, allowing them to germinate simultaneously. The treatment of scarification in sandpaper with immersion in water for 24 hours at room temperature showed good performance (Figure 4).

Revista Árvore 2021;45:e4532 


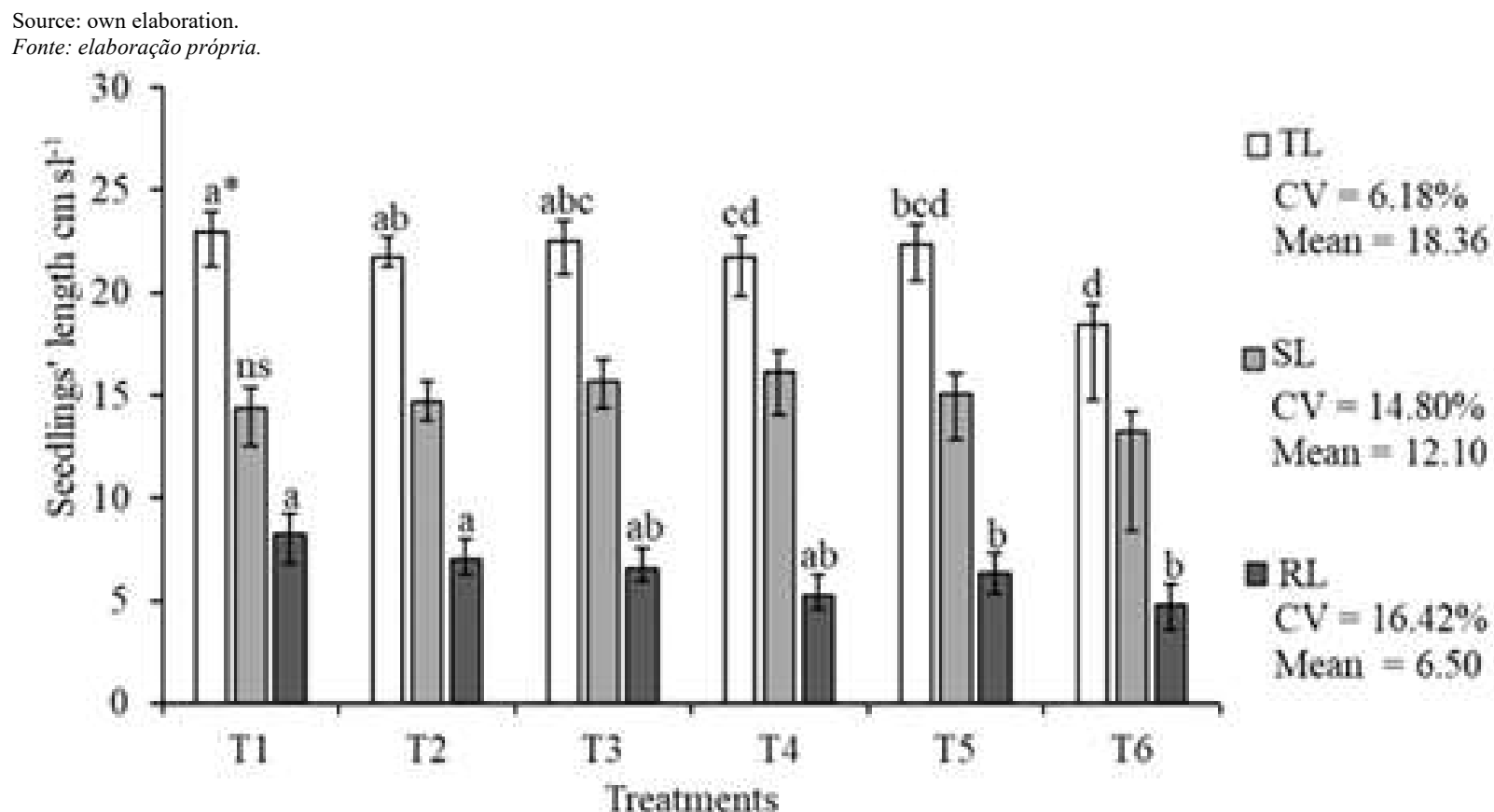

Figure 2 - Results for the Total Length (TL), Shoot Length (SL), and Root Length (RL) of Ormosia grossa seedlings. T $=$ scarification with 80 -grit sandpaper and immersion in water at room temperature for 24 hours; $\mathrm{T}_{2}=$ puncturing and immersion in water at room temperature for 24 hours; $\mathrm{T}_{3}=$ scarification with 80 -grit sandpaper; $\mathrm{T}_{4}=$ puncturing; $\mathrm{T}_{5}=$ immersion in water heated at $80{ }^{\circ} \mathrm{C}$ for five minutes and $\mathrm{T}_{6}=$ control - seeds with no treatment. Mean values followed by the same letters, comparing the cited treatments, did not hold a significant difference by the Tukey test $(\mathrm{P}<0.05)$. *represents the existence of difference between variables. Bars represent the standard error of the mean of four repetitions and non-significant ${ }^{\mathrm{ns}},(\mathrm{s} \mathrm{l}=\mathrm{seedling}), \mathrm{CV}=\mathrm{coefficient}$ of variation.

Figura 2 - Resultados para comprimento total $(C T=T L)$, comprimento de parte aérea $(C P A=S L)$ e comprimento raiz de plântulas $(C R=R L)$ de Ormosia grossa. $T_{1}=$ escarificação com lixa número 80 e embebição em água à temperatura ambiente por 24 horas; $T_{2}=$ punção e embebição em água à temperatura ambiente por 24 horas; $T_{3}=$ escarificação com lixa número 80; $T_{4}=$ punção; $T_{5}=$ imersão em água aquecida a $80^{\circ} \mathrm{C}$ por cinco minutos e To=Controle-sementes sem nenhum tratamento. Médias seguidas por letras iguais, comparando os diferentes tratamentos apresentados, não diferem entre si pelo teste de Tukey $(P<0,05)$ *representa a existência de diferença entres as variáveis. Barras representam o erro padrão da média de quatro repetições e ${ }^{n}$ não significativo. $(s l=p l=$ Plântula $), C V=$ coeficiente de variação.

\section{DISCUSSION}

The methods used to overcome dormancy in the seeds of Ormosia grossa through germination showed that the scarification in sandpaper with water immersion (T1) provided better germination uniformity, a greater number of normal seedlings, and a smaller number of hard seeds among the evaluated treatments. According to Nascimento et al. (2021), scarification with sandpaper allows obtaining more homogeneous and synchronous germination, which is desirable in the production of seedlings, in addition to not incurring damage to the environment. And in the case of this study, it appears that immersion in water for a certain period contributes more to the germination process, with faster metabolic activation.

High germination is also associated with high vigor and seed germination speed (GSI, MGT, and
MGS). This parameter is indicated to detect differences in vigor between lots - meaning that those with the highest germination speed also are the most vigorous (Krzyzanowski et al., 1999) - and can also be used to evaluate different treatments for the same lot of seeds. In this context, all metabolic processes for germination are activated allowing, to a lesser or greater degree, the germination time, which is constituted by the difference between treatments applied in relation to the vigor - measured by the GSI and MGS. Therefore, vigor is not an easily measured characteristic, but a concept that gathers a set of characteristics associated with seeds' performance (ISTA, 2011).

The pre-germination treatments which determined the highest percentages and average germination time of the seeds were sandpaper scarification, water soaking, and water soaking followed by sandpaper. Although the methods of abrasiveness and perforation

Revista Árvore 2021;45:e4532 
Source: the authors. Fonte: elaboração própria.

Fonte: elaboração própria.
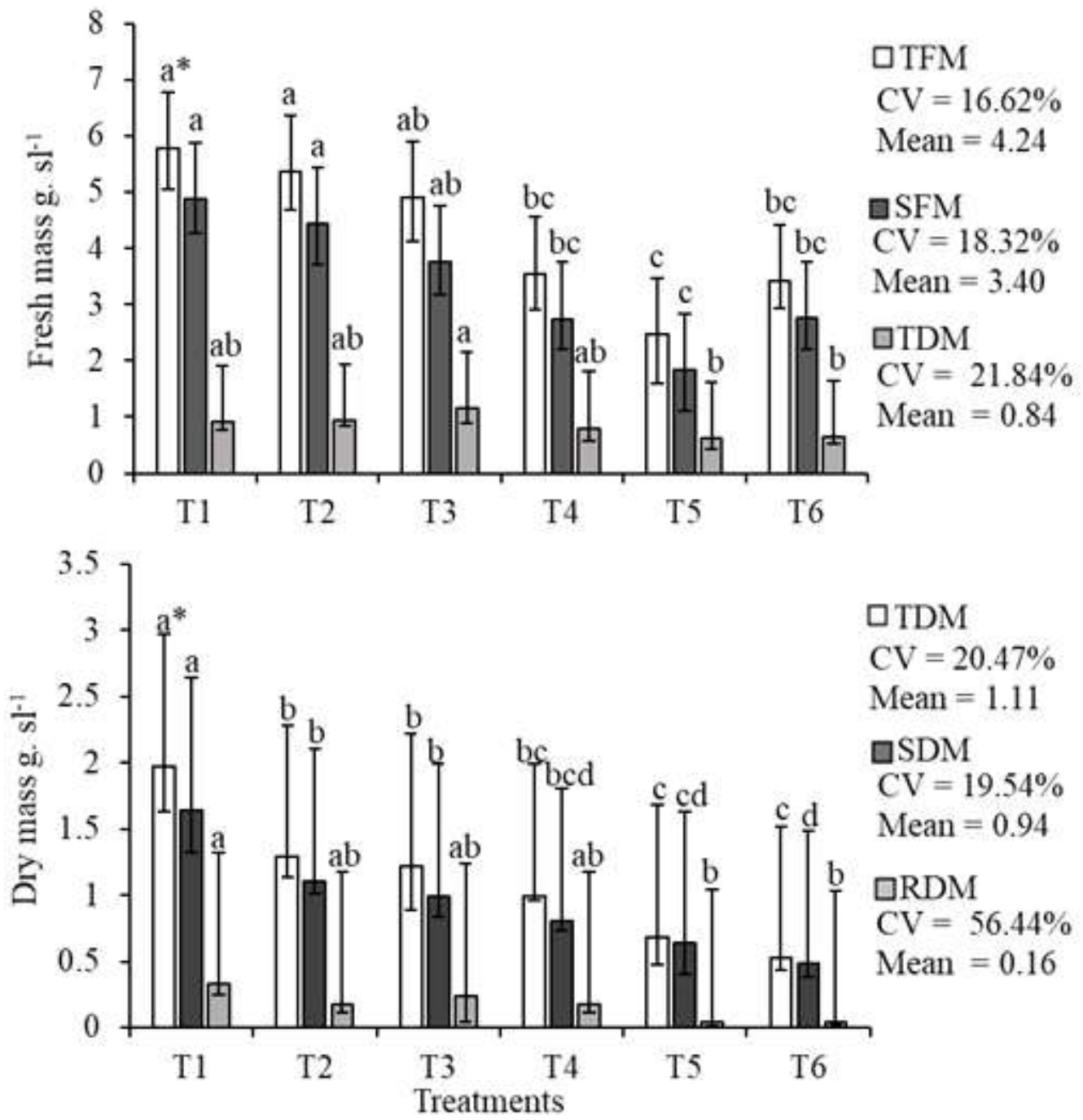

Figure 3 - Results of seedling mass (TFM= Total Fresh Mass), (SFM= Shoot Fresh Mass), (RFM= Root Fresh Mass), (TDM= Total Dry Mass), (SDM= Shoot Dry Mass), (RDM= Root Dry Mass) of Ormosia grossa $\left(\mathrm{sl}=\right.$ seedling). $\mathrm{CV}=$ coefficient of variation. $\mathrm{T}_{1}=$ scarification with 80-grit sandpaper and immersion in water at room temperature for 24 hours; $\mathrm{T}_{2}=$ puncturing and immersion in water at room temperature for 24 hours; $\mathrm{T}_{3}=$ scarification with 80 -grit sandpaper; $\mathrm{T}_{4}=$ puncturing; $\mathrm{T}_{5}=$ immersion in water heated at $80{ }^{\circ} \mathrm{C}$ for five minutes and $\mathrm{T} 6=$ control - seeds with no treatment. Mean values followed by the same letters, comparing the cited treatments, did not hold a significant difference by the Tukey test $(\mathrm{P}<0.05)$. *represents the existence of difference between variables. Bars represent the standard error of the mean of four repetitions.

Figura 3 - Resultados de massa das plântulas (TFM=MFT= massa fresca total), (SFM=MFPA= massa fresca da parte aérea), $(R F M=M F P R=$ massa fresca da parte raiz), $(T D M=M S T=$ massa seca total $),(S D M=M S P A=$ massa seca de parte aérea $)$, $\left(R D M=M S P R=\right.$ massa seca parte raiz) de Ormosia grossa. $($ sl $=$ pl= Plântula $) . C V=$ coeficiente de variação. $T_{1}=$ escarificação com lixa número 80 e embebição em água à temperatura ambiente por 24 horas; $T_{2}=$ punção e embebição em água à temperatura ambiente por 24 horas; $T_{3}=$ escarificação com lixa número 80; $T_{4}=$ punção; $T_{5}=$ imersão em água aquecida a $80{ }^{\circ} \mathrm{C}$ por cinco minutos e $T_{6}=$ Controle-sementes sem nenhum tratamento.

added in water may show more effective results in overcoming dormancy, these treatments require greater care not to cause damage to the embryo (Lopes et al., 1998). Despite being an effective method, manual scarification of seeds makes the process of obtaining seedlings time-consuming and requires knowledge of the seed's internal and external morphology (Silva et al., 2020a). Studies demonstrate 

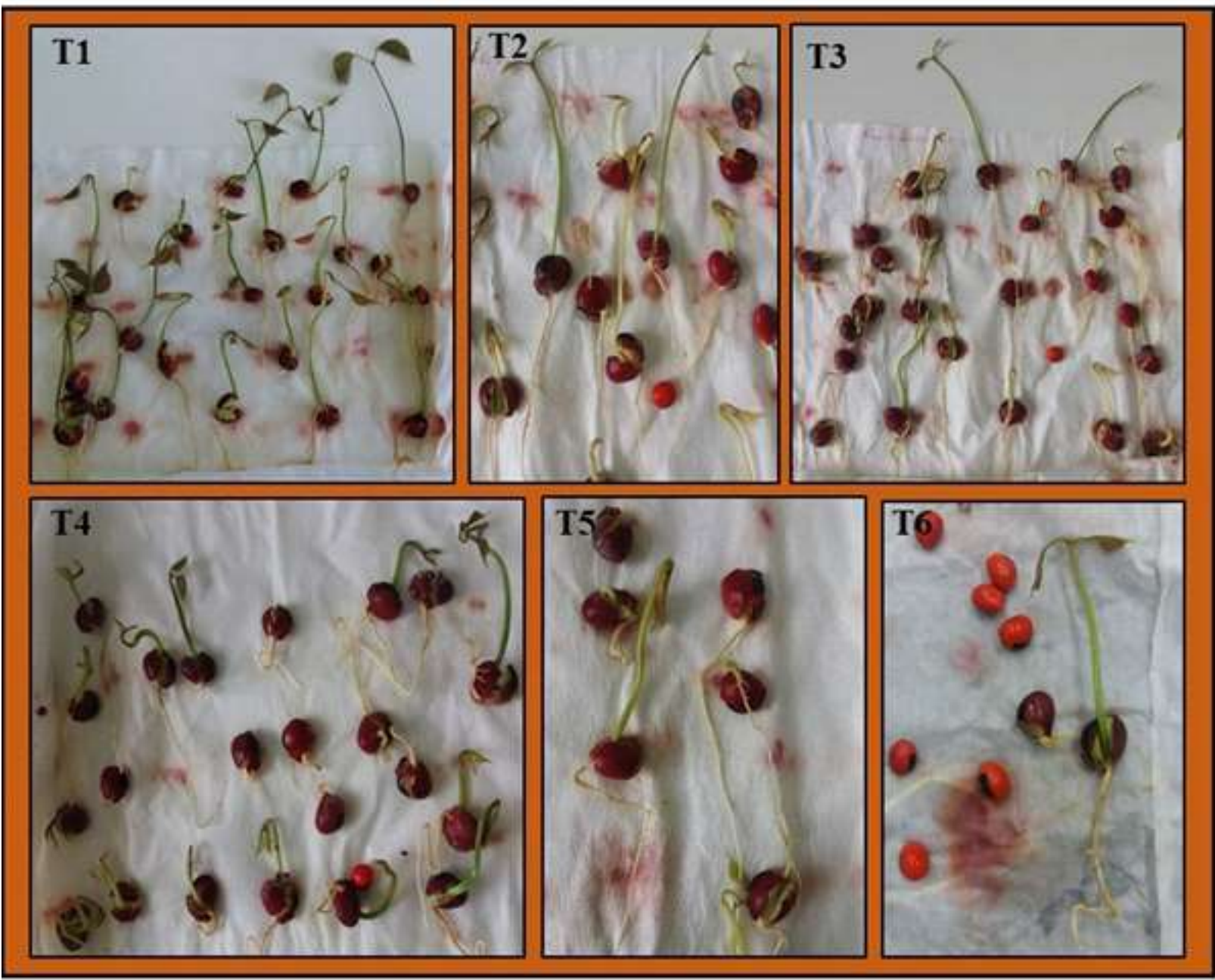

Figure 4 - Illustration of germination and seedling performance after dormancy overcoming methods in Ormosia grossa seeds. $\mathrm{T}_{1}=80$-grit sandpaper scarification and 24-hours immersion in water at room temperature; $\mathrm{T}_{2}=$ Puncturing and 24-hours immersion in water at room temperature; $\mathrm{T}_{3}=80$-grit sandpaper scarification; $\mathrm{T}_{4}=$ puncturing; $\mathrm{T}_{5}=$ immersion in water heated at $80^{\circ} \mathrm{C}$ for five minutes and $\mathrm{T}_{6}=$ Control: - seeds without any treatment to overcome dormancy.

Figura 4 - Ilustração do desempenho germinativo e de plântulas após métodos de superação de dormência em sementes de Ormosia grossa. $T_{1}=$ escarificação com lixa número 80 e embebição em água à temperatura ambiente por 24 horas; $T_{2}=$ punção e embebição em água à temperatura ambiente por 24 horas; $T_{3}=$ escarificação com lixa número 80; $T_{4}=$ punção; $T_{5}=$ imersão em água aquecida a $80^{\circ} \mathrm{C}$ por cinco minutos e $T_{6}=$ Controle- sementes sem nenhum tratamento.

this method's applicability as a better response in the germination of dormant seeds of some tree species, such as Piptadenia stipulacea (Benth.) Ducke, Cassia fistula L. and Cassia leptophylla Vogel (Padilha et al., 2018; Benedito et al., 2019; Cruz et al., 2019).

The treatment with immersion in heated water 80 ${ }^{\circ} \mathrm{C} / 5^{\prime}$ demonstrates that the method could not fully overcome seed dormancy of Ormosia grossa. It was also found that the seeds exposed for five minutes remained viable. It is possible to notice that this method did not significantly overcome seed dormancy since the germination in this treatment was the same as the others that obtained an opening in the seed coat. This may occur because the mother plant develops control mechanisms in progeny seeds, where the seed receives information from the mother plant when it detects high temperature silencing the genes that do not allow germination. The seed can perceive

Revista Árvore 2021;45:e4532 
temperature variation in up to $1{ }^{\circ} \mathrm{C}$ difference in the environment (Chen et al., 2014).

Immersion in water with high temperatures may cause the embryo to die or not. In the case of Ormosia grossa seeds exposed to $80{ }^{\circ} \mathrm{C}$ for five minutes, dead seeds were not verified. The maternal processes, together with the gene expressions in the zygote that act in blocking the seeds' metabolic activity, may explain the fact that some seeds germinate and others do not. Penfield (2017), reports that the environmental signs are perceived by the mother plant and the developing zygote and are used to control the germination in progeny seed. The result is that a mother plant can transmit seasonal information to a progeny and also use environmental changes to generate variations in the progeny's dormancy states. The temperature that the mother plant experiences throughout its life cycle, including whether the plant undergoes vernalization or not, both have significant impacts on its progeny's seed dormancy (Springthorpe and Penfield, 2015).

Ormosia grossa occurs in a place with temperatures ranging from 30 to $37{ }^{\circ} \mathrm{C}$, allowing these environmental perceptions between the mother plant and the zygote. Under these conditions, seed growth may be blocked, and reserves build up. In most species, the acquisition of tolerance to low water content allows the seed to survive in humid or dry places for long periods in the environment (Penfield, 2017).

In studies with Enterolobium contortisiliquum (Vell.) Morong., Silva et al. (2020b), applied heat treatments in dry heat using 60,80 , and $105^{\circ} \mathrm{C}$ for 5 minutes and found that it was not enough to overcome seed dormancy. It is believed that heat treatments can be pretty advantageous due to the practicality of execution, allowing to work with high numbers of seeds. On the other hand, mechanical scarification allows the highest values of germination. However, the process is slow since one works with few seeds or even one at a time. The germination frequency distribution tending to the right showed a shorter mean germination time than the predicted in the Forest Species Seed Analysis (MAPA, 2013) for the same genus species (Ormosia), which indicates 21 days for the first counting and 28 days for the final counting. In Ormosia nitida, the germination time has also been reduced by the administration of a dormancy overcoming treatment with mechanical scarification, demonstrating germination uniformity (Lopes et al., 2006).

According to Pinheiro et al. (2017), when the polygonal line displacement to the right does not touch the horizontal axis, there are several daily germination occurrences. Otherwise, after germination, the peaks represented in non-collinear lines, when touching (or approaching) the horizontal axis, generate unequal germination peaks, showing no germination in the observed days of some of the repetitions. So, through the frequencies, it is possible to observe that, over time, the seeds germinate until reaching maximum value and then decline (Santana and Ranal, 2004).

The seedling length results demonstrate the variables were quite similar, evidencing that even when applying pre-germinative treatment, the growth did not have a high expressiveness in the differences for seedling growth. Taking such characteristics (total length, root length, and shoot length of the seedling) into consideration for forest species is an important factor for seedlings transplanting because, depending on the size class, it is a way of making decisions to take to the fields and succeed in establishing the seedlings and achieve a higher survival rate (Viani and Rodrigues, 2007).

The fresh mass and dry mass of seedlings are some of the patterns to evaluate the plant's growth (Figure $3)$. However, it is possible to accurately determine the transfer from the organic material from the reserve tissues to the embryonic axis by the evaluation of the dry mass of the seedlings (Krzyzanowski et al., 1999).

The perforation of the integument with puncturing and the sandpaper scarification eliminate integumentary dormancy, accelerate and unify seed germination and seedlings emergence the Schizolobium amazonicum Herb (Dapont et al., 2014). According to Pacheco et al. (2014), mechanical sandpaper scarification and water soaking for 24 hours pre-germinative treatments allow for better expression of the seeds and vigor of seedlings of Combretum leprosum Mart. This was also verified in the results of this study.

\section{CONCLUSION}

Ormosia grossa seeds present dormancy due to integument impermeability. Treatments

Revista Árvore 2021;45:e4532 
with scarification by abrasiveness are efficient in overcoming dormancy, increasing germination speed and percentage. Therefore, it is recommended the method of scarification with sandpaper followed by seed imbibition in water at room temperature for 24 hours, as it provides the best seedling performance and germination.

\section{AUTHOR CONTRIBUTIONS}

Pinheiro RM: data analyze and text written, Soares NS and Almeida AS: research supervision and text review, Gadotti GI: technical review and Silva EJS: text review and translation.

\section{ACKNOWLEDGEMENTS}

The presented study was performed with the support of the Coordination for the Improvement of Higher Education Personnel - Brazil (CAPES) Financing Code 001.

\section{REFERENCES}

Araújo PC, Araujo Neto AC, Santos SRN, Medeiros JGF, Leite RP, Alves EU. Biometria de frutos e sementes de Operculina macrocarpa (L.) Urban ocorrente no semiárido Norte-Riograndense. Scientia Plena. 2012;8(4), 1-5

Basqueira RA, Pessa, H, Souza-Leal T, Pedroso-deMoraes C. Superação de dormência em Ormosia arborea (Fabaceae: Papilionoideae) pela utilização de dois métodos de escarificação mecânica em diferentes pontos do tegumento. Revista em Agronegócios e Meio Ambiente. 2011;4(3),547-561. doi: $10.17765 / 2176-9168.2011 v 4 n 3 p \% 25 p$

Benedito CP, Ribeiro MCC, Paiva EP, Medeiros HLS. Dormancy overcoming and germination test in Piptadenia stipulacea (Benth.) Ducke seeds. Revista Ciência Agronômica. 2019;50(2),338-344. doi: $10.5935 / 1806-6690.20190040$

Ministério da Agricultura, Pecuária e Abastecimento - Mapa. Regras para análise de sementes. Brasília: Assessoria de Comunicação Social, 2009. ISBN: 978-85-99851-70-8

Carvalho NM, Nakagawa J. Sementes: ciência, tecnologia e produção. $5^{\text {a }}$. ed. Jaboticabal: FUNEP; 2012. ISBN: 978-85-7805-090-0
Chen M, MacGregor DR, Dave A, Florance H, Moore K, Paszkiewicz K, Smirnoff N, Graham IA, Penfield S. Maternal temperature history activates flowering Locus $\mathrm{T}$ in fruits to control progeny dormancy according to time of year. National Academy of Sciences. 2014;111(52),18787-18792. doi: 10.1073/pnas.1412274111

Cruz YF, Mendonça AP, Carvalho MBF, Salvatierra YVD, Chaves NMC, Dorado A J. Métodos de superação de dormência de canafístula (Cassia fistula L.). Revista Brasileira de Ciência da Amazônia. 2019;8(1),007-011. doi: 10.47209/2317-5729.v.8.n.1 .p. 7-11

Dapont EC, Silva JB, Oliveira JD, Alves CZ, Dutra AS. Métodos para acelerar e uniformizar a emergência de plântulas de Schizolobium amazonicum. Revista Ciência Agronômica. 2014;45(3),598-605. doi: 10.1590/S180666902014000300022

Gama JSN, Alves EU, Bruno RLA, Pereira Junior LR, Braga Junior JM, Monte DMO. Superação de dormência em sementes de Centrosema plumieri Benth. Revista Brasileira de Sementes. 2011;33(4),643-651. doi: 10.1590/S010131222011000400006

International Seed Testing Association - ISTA. Proposed Changes to the ISTA International Rules for Seed Testing. 2011,(142):60,Oct. [cited 2020 Sept ]. Available from: https://ww w.seedtest.org/upload/ cms/user/STI_142_Oct_2011_web.pdf

Jayasuriya KMGG, Baskin JM, Geneve, RL, Baskin, CC. Morphology and anatomy of physical dormancy in Ipomoea lacunosa: identification of the water gap in seeds of Convolvulaceae (Solanales). Annals of Botany. 2007;100(1):13-22. doi: 10.1093/aob/ $\operatorname{mcm} 070$

Kang J, Yim H, Choi S, Kim A, Lee KP, LopezMolina L, et al. Abscisic acid transporters cooperate to control seed germination. Nature Communications. 2015;6,8113. doi: $10.1038 / \mathrm{n}$ comms 9113

Krzyzanowski FC, Vieira, RD, França Neto JB, editors. Vigor de sementes: conceitos e testes. Londrina: ABRATES, 1999. ISBN: 978-65-9920000-7

Revista Árvore 2021;45:e4532 
Labouriau LG, Valadares MEB. On the germination of seeds Calotropis procera (Ait.) Ait.f. Anais da Academia Brasileira de Ciências. 1976;48(2),263284

Lopes JC, Capucho MT, Krohling B, Zanotti, P. Germinação de sementes de espécies florestais de Caesalpinia ferrea Mart. ex. Tul. var. leiostachya., Cassia grandis L. e Samanea saman Merrill, após tratamentos para superar a dormência. Revista Brasileira de Sementes. 1998;20(1),80-86

Lopes JC, Dias PC, Macedo CMP de. Tratamentos para acelerar a germinação e reduzir a deterioração de sementes de Ormosia nitida Vog. Revista Árvore. 2006;30(2),171-177. doi: 10.1590/S010067622006000200003

Lopes RR, Franke LB. Aspectos térmico-biológicos da germinação de sementes de cornichão anual sob diferentes temperaturas. Revista Brasileira de Zootecnia. 2011;40(10),2091-2096. doi: 10.1590/ S1516-35982011001000004

Lorenzi H. Árvores Brasileiras: manual de identificação e cultivo de plantas arbóreas nativas do Brasil. $5^{\text {a }}$. ed. Nova Odessa: Instituto Plantarum; 2010.v.1. ISBN: 978-8586714504

Machado AA, Conceição AR, Silva JGCE, Campari CAP, Júnior PS, Porenstein D, Krolow Rala, Gonsales AD, Junior JCV. WinStat. Sistemas de análises estatísticas para Windows. NIA - Núcleo de Informática Aplicada. Version 2.11. Pelotas, PR: UFPEL - Universidade Federal de Pelotas; 2001

Ministério da Agricultura Pecuária e Abastecimento - MAPA. Instruções para Análise de Sementes de Espécies Florestais. 2013,98p. [cited 2019 May.]. Available from: https://www.gov.br/agricultura/pt-br/ assuntos/insumos-agropecuarios/insumos-agricolas/ seme ntes-e-mudas/publicacoes-sementes-e-mudas/ instrucoes-para-analise-de-sementes-de-especies -florestais/view

Nascimento EV, Bonilla, OH, Lucena, EMP, Nascimento, SF, Farias, IBM, Sousa, LH. Superação de dormência em sementes da Cassia grandis L.f. (Fabaceae). Revista Verde de Agroecologia e Desenvolvimento Sustentável. 2021;16,89-96. doi: 10.18378/rvads.v16i1.75 41

Pacheco MV, Araújo FS, Ferrari CS, Bruno, RLA.
Germinação de sementes de Combretum leprosum Mart. Caatinga. 2014;27(1),154-162

Padilha MS, Sobra LS, Abreu L. Métodos para superação da dormência em sementes de Cassia leptophylla Vogel. Revista Ciência Agrícola. 2018;16(2),1-8. doi: 10.28998 /rca.v16i2.4154

Penfield S. Seed dormancy and germination. Current Biology. 2017;27(17): R874-R878. doi: 10.1016/j. cub.2017.05.050

Pinheiro RM, Ferreira EJL, Carvalho GFS. Aspectos germinativo e biométrico de copaíba (Copaifera paupera (Herzog) Dwyer. Fabaceae). Revista Congrega Urcamp (cd-rom). 2017;(14),39-44

Santana DG, Ranal MA. Análise da germinação: um enfoque estatístico. Brasília: Editora Universidade de Brasília; 2004. ISBN: 9788523007911

Silva GIN da, Araujo ABN de, Ferraz ACN, Silva CX da, Silva MAD da. Utilização de diferentes tratamentos pré-germinativos para superação de dormência em sementes de Adenanthera pavonina L. Diversitas Journal. 2020a;5(2),754-62. doi: 10.17648/diversitas-journal-v5i2-1044

Silva BRF, Lucas FMF, Costa TLN da, Azevêdo TKB. Tratamentos térmicos para a superação de dormência em sementes de uma espécie arbórea brasileira. Journal of Biotechnology and Biodiversity. 2020b;8(3),219-224. doi: 10.20873/jbb.uft.cemaf. v8n3.silva

Springthorpe V, Penfield S. Flowering time and seed dormancy control use external coincidence to generate life history strategy. eLife. 2015;4,e05557. doi: $10.7554 /$ eLife. 05557

Tognacca, RS, Botto, JF. Post-transcriptional regulation of seed dormancy and germination: current understanding and future directions, Plant Communications. 2021,100169. doi: 10.1016/j. xplc. 2021.100169

Venier P, Funes G, García CC. Physical dormancy and histological features of seeds of five Acacia species (Fabaceae) from xerophytic forests in central Argentina. Flora - Morphology, Distribution, Functional Ecology of Plants, 2012;207(1),39-46. doi: 10.1016/j.flora.2011.07.017

Revista Árvore 2021;45:e4532 
Viani RAG, Rodrigues RR. Sobrevivência em viveiro de mudas de espécies nativas retiradas da regeneração natural de remanescente florestal.
Pesquisa Agropecuária Brasileira, Brasília, 2007;42(8),1067-1075, ago. doi: 10.1590/S0100204X2007000800002

Revista Árvore 2021;45:e4532 